\title{
Alicyclobacillus acidoterrestris spores as a target for Cupuaçu (Theobroma grandiflorum) nectar thermal processing: kinetic parameters and experimental methods
}

\author{
Margarida C. Vieira ${ }^{\mathrm{a}}$, Arthur A. Teixeira ${ }^{\mathrm{b}}$, Filipa M. Silva ${ }^{\mathrm{c}}$, \\ Nelma Gaspar ${ }^{\mathrm{a}}$, Cristina L.M. Silva ${ }^{\mathrm{c}, *}$ \\ ${ }^{a}$ Escola Superior de Tecnologia, Universidade do Algarve, Campus da Penha, 8000 Faro, Portugal \\ ${ }^{\mathrm{b}}$ Agricultural and Biological Engineering Department, University of Florida, P.O. Box 110570, Gainesville, FL 32611-0570, USA \\ ${ }^{\mathrm{c}}$ Escola Superior de Biotecnologia, Universidade Católica Portuguesa, Rua Dr. António Bernardino de Almeida, $4200-072$ Oporto, Portugal
}

\begin{abstract}
The kinetic parameters of thermal inactivation of a spore former, Alicyclobacillus acidoterrestris, in a tropical fruit nectar [25\% of Cupuaçu (Theobroma grandiflorum) pulp and $15 \%$ sugar] were determined by the isothermal method (IM), under batch heating, and by the paired equivalent isothermal exposures (PEIE) method, under non-isothermal continuous conditions. The isothermal experiments were repeated three times, every 4 months, with the same spore suspension kept frozen between experiments. The aging of spores, under frozen storage, seemed to produce a notorious increase in the $z$-value from experiment to experiment: Experiment $1\left(z=7.8 \pm 2.6{ }^{\circ} \mathrm{C}, D_{95}{ }^{\circ} \mathrm{C}=5.29 \pm 0.96 \mathrm{~min}\right)$, Experiment $2\left(z=22 \pm 5{ }^{\circ} \mathrm{C}, D_{95}{ }^{\circ} \mathrm{C}=5.99 \pm 0.63\right.$ min), and Experiment $3\left(z=29 \pm 10{ }^{\circ} \mathrm{C}, D_{95}{ }^{\circ} \mathrm{C}=3.82 \pm 0.48 \mathrm{~min}\right)$. The evaluation of the kinetic parameters by the PEIE method was carried out in parallel with Experiment 3, with the same aged spores, and the results $\left(z=31 \pm 6{ }^{\circ} \mathrm{C}, D_{95}\right.$ ${ }^{\circ} \mathrm{C}=5.5 \pm 1.2 \mathrm{~min}$ ) were close to the ones obtained in this experiment. From this work, it seems that the PEIE method can also be applied to evaluate the reduction parameters of a spore-forming microorganism, and in a more realistic way, since the continuous system eliminates the errors caused by come-up and cool-down times (CUT and CDT) that are unavoidable in isothermal experiments. Therefore, when designing a thermal process for a continuous system, the PEIE method should be used, or the chances are that the process would be underdesigned, risking that the desired level of spore inactivation would not be achieved. An optimization of the thermal processing conditions was next performed for Cupuaçu nectar, considering a $5 D$ reduction in $A$. acidoterrestris spores. If a pasteurization process is considered, the conditions that ensure safety $(9 \mathrm{~min}$ at 98 ${ }^{\circ} \mathrm{C}$ ) only allow a $55 \%$ retention of ascorbic acid (AA). If sterilization is considered, $8 \mathrm{~s}$ at $115{ }^{\circ} \mathrm{C}$ will ensure a safe product and retain $98.5 \%$ of the original ascorbic acid. Therefore, if A. acidoterrestris is considered as the target microorganism, the nectar should undergo an aseptic high temperature short time principle (HTST) process to achieve a $5 D$ reduction in this acidophilus spore former. However, if the hot-fill-and-hold pasteurization process is preferred, the product should be fortified with ascorbic acid.
\end{abstract}

Keywords: Alicyciclobacillus acidoterrestris spores; Inactivation kinetics; PEIE method; Isothermal method; Cupuaçu (Theobroma grandiflorum) nectar

\footnotetext{
${ }^{*}$ Corresponding author. Tel.: +351-22-5580058; fax: +351-22-5090351.

E-mail addresses: mvieira@ualg.pt (M.C. Vieira), atex@agen.ufl.edu (A.A. Teixeira), crislui@esb.ucp.pt (C.L.M. Silva).
} 


\section{Introduction}

When designing a thermal process to produce shelf stable juices or nectars (which usually have low $\mathrm{pH}$, $\mathrm{pH}<4.5$ ), Clostridium botulinum is not a concern since it is generally accepted that the spores of this microorganism will not grow or produce toxin at $\mathrm{pH}<4.6$ (Blocher and Busta, 1983). Yeast, molds, and some nonspore-forming bacteria (e.g. Lactobacillus plantarum) are therefore, the most probable spoilage flora. To destroy this flora, a pasteurization process is enough and acid fruit juices have been processed for years by hot-fill-and-hold pasteurization systems. The product is heated to approximately $90-$ $95{ }^{\circ} \mathrm{C}$ during a holding time of approximately $15-20$ $\mathrm{s}$, followed by a cooling period until $82-84{ }^{\circ} \mathrm{C}$, before filling the product into the package. Next, it is held hot for about 2 min before the packages are cooled down in a cooling tunnel (Solberg et al., 1990). However, in the 1980s, the fruit juice industry started facing a serious problem: consumer complains about spoiled juices long before their shelf life had expired. An off flavor and sometimes loss of color were the main complaints (Walls and Chuyate, 1998). As no gas production was reported, in some cases, it was thought to be a chemical contamination, but with time, it was concluded to be due to microbial growth (Walls and Chuyate, 1998). Only a spore former could survive a thermal treatment in the pasteurization range, and it had to be acidophilic to grow in acid juices. There was already some evidence that acidophilic spore formers existed, such as Bacillus coagulans, known to spoil tomato paste and juice (York et al., 1975; Rodrigo et al., 1990; Sandoval et al., 1992). The microbial growth on apple juice was isolated and identified as a new type of spoilage bacterium (Cerny et al., 1984), and named by Deinhard et al. (1987) as $B$. acidoterrestris. Later, it was reclassified as a new genus Alicyclobacillus, becoming Alicyclobacillus acidoterrestris (A. acidoterrestris), which together with $A$. acidocaldarius and $A$. heptanicus had in common the presence of a $\omega$-alicyclic fatty acid as the major fatty acid in the cell membrane (Yamazaki et al., 1996). Closely packed rings of this fatty acid form a protective coating to the cellular membrane, explaining the resistance of these three microorganisms to acid environments (Pontius et al., 1998; Walls and Chuyate, 1998).
The effect of different acids (citric, tartaric, and malic acids) on the heat resistance of $A$. acidoterrestris spores was studied in model systems by Pontius et al. (1998). No significant differences were shown in the temperature range studied $\left(91-100{ }^{\circ} \mathrm{C}\right)$, although the type of acid seemed to have a more severe effect at temperatures below $91{ }^{\circ} \mathrm{C}$. Soluble solids (Brix) concentration had a major influence on growth (Splittstoesser et al., 1994). It was reported that for white grape juice made from Riesling grapes, a $19.2^{\circ}$ Brix would inhibit growth, whereas $18.2^{\circ}$ Brix would be the optimum value for growth to occur. Silva et al. (1999) developed a predictive model for $D$ values as a function of $\mathrm{pH}$, soluble solids, and temperature of the environment. A recommendation about redesigning thermal processes for juices, endangered by this microorganism, was made by Pontius et al. (1998), and for new fruit juices or juice mixes, this acidophilic spore former should become a concern.

The design of a thermal process should include an optimization, in order to make sure that the level of inactivation, required for the target microorganism, is satisfied without impairing the quality of the food product. An optimization process involves several factors (Teixeira and Shoemaker, 1989): (1) an objective function, which in thermal processing is usually identified as the maximization of a quality attribute; (2) decision variables, adjustable and with an independent nature. These are variables that affect the value of the objective function. In thermal processing, they are specific of the process model, e.g. temperature of heating fluid, flow rate of product to be processed, etc.; (3) a set of constraints allowing the decision variables to take certain values, but not others, to deal with equipment limitations. They can also be imposed by safety requirements, e.g. level of reduction on a microorganism in order to keep the product safe; (4) a process mathematical model, since process simulation allows prediction of the objective function by constraining the decision variables; and (5) the optimization technique to be chosen. If only a few variables are defined, producing a limited number of solutions, a very simple optimization technique can be used based on a search for the best solution that best satisfies the requirements imposed by the objective function in the mathematical model.

For the reasons mentioned above and considering the $\mathrm{pH}$ and Brix of the Cupuaçu nectar $(\mathrm{pH} \cong 3.2$ and 
$18^{\circ}$ Brix), A. acidoterrestris was considered a target microorganism for the design of a thermal process for this product. The main objectives of the work presented in this article were: (i) to model the thermal inactivation kinetics of $A$. acidoterrestris spores in Cupuaçu (Theobroma grandiflorum) nectar using two methods, the isothermal method (IM) and the paired equivalent isothermal exposures (PEIE) method (Welt et al., 1997; Vieira et al., 2000, 2001); (ii) to optimize the thermal process conditions, maximizing ascorbic acid (AA) retention of the product.

\subsection{Theoretical considerations}

Destruction of microorganisms does not imply physical destruction, but loss of viability (maybe due to the inactivation of an enzyme) (Geankoplis, 1993). First-order kinetics can represent the death-rate behavior of microorganisms,

$C=C_{0} \mathrm{e}^{-k t}$

where $C_{0}$ is the initial concentration, $C$ is the concentration at time $t, k$ is the rate constant, and $t$ is the time of thermal exposure.

Thermobacteriologists prefer to describe microorganisms thermal inactivation first order reaction kinetics in terms of decimal logarithmic reduction (Eq. (2)) (Stumbo, 1973; Etsy and Myer, 1922; Geankoplis, 1993),

$N=N_{0} 10^{-\left(t / D_{T}\right)}$

where $N_{0}$ is the number of initial microbial population and $N$ is the number of survivor microbial population at a given time. The thermal reduction time $(D)$, defined by microbiologists as the time it takes for a population of microorganisms to be reduced by $90 \%$, is related to the rate constant (k) (Geankoplis, 1993),

$D=\frac{2.303}{k}$.

The temperature dependency of the rate constant $(k)$ can be described by the Bigelow model (Bigelow, 1921),

$D_{T}=D_{T_{\mathrm{ref}}} 10^{-(1 / z)\left(T-T_{\mathrm{ref}}\right)}$.
The isothermal method (IM) (Lenz and Lund, 1980) is not ideal for estimation of thermal kinetic parameters of reactants because of unavoidable errors caused by come-up and cool-down times. Swartzel (1982) developed the equivalent point method (EPM), one of the first methods implemented to overcome this problem. In this method, a $G$ value was first introduced which is a function of the time-temperature history $T(t)$ (Swartzel, 1982),

$G=\frac{\ln \frac{C}{C_{0}}}{-k_{0}}=\int_{0}^{t} \exp \left(-\frac{E_{\mathrm{a}}}{R T(t)}\right) \mathrm{d} t$

where $k_{0}\left(\mathrm{~min}^{-1}\right)$ is the rate constant at infinite reference temperature, $E_{\mathrm{a}}(\mathrm{kJ} / \mathrm{mol})$ is the activation energy, and $R$ is the universal gas constant.

This method postulated that in continuous heating, depending on the $E_{\mathrm{a}}$ values (different activation energies) and $G$ values (different thermal exposures), different lines would be produced all intersecting in one point, the equivalent point, defined by an equivalent time and temperature $\left(t_{\mathrm{E}}, T_{\mathrm{E}}\right)$, equivalent isothermal exposure,

$G=t_{\mathrm{E}} \exp \left(-\frac{E_{\mathrm{a}}}{R T_{\mathrm{E}}}\right)$.

However, deviations to this intersection were verified (Maesmans et al., 1995; Welt et al., 1997). In order to avoid this problem, new methods were developed based on modifications on EPM, such as the line intersection (LI) method (Kyereme et al., 1999) and the paired equivalent isothermal exposures (PEIE) method. The latter, being iterative, gives at the end of the iterative procedure an equivalent isothermal exposure (EIE) for each combination $\left(T_{\mathrm{E}}\right.$ and $t_{\mathrm{E}}$ are determined by solving Eqs. (7a) and (7b), simultaneously):

$\ln t_{\mathrm{E}}=\ln G_{1}+\frac{E_{\mathrm{a}_{1}}}{R T_{\mathrm{E}}}$

$\ln t_{\mathrm{E}}=\ln G_{2}+\frac{E_{\mathrm{a}_{2}}}{R T_{\mathrm{E}}}$.

The corresponding isothermal rate constants, $k_{\mathrm{E}}$ 's, are next determined for each thermal exposure,

$k_{\mathrm{E}}=-\frac{\ln \left(C / C_{0}\right)_{\exp }}{t_{\mathrm{E}}}$. 
An Arrhenius curve is then obtained by plotting $\ln k_{\mathrm{E}}$ vs. $1 / T_{\mathrm{E}}$, where the slope gives a new $E_{\mathrm{a}_{1}}$ and the $y$-intercept, the $k_{\text {ref }}$ (dynamic set). The generation of a new $E_{\mathrm{a}_{2}}$, as a multiple or submultiple of $E_{\mathrm{a}_{1}}$, initiates a new iteration. This iterative procedure continues until there is no difference between the dynamic sets obtained in two consecutive iterations.

The PEIE method can be slightly modified to apply the Bigelow model (Bigelow, 1921). The corresponding isothermal $D$ values, $D_{\mathrm{E}}$ 's, are then determined for each thermal exposure,

$D_{\mathrm{E}}=-\frac{t_{\mathrm{E}}}{\log \left(N / N_{0}\right)}$

and from a plot of $\log D_{\mathrm{E}}$ vs. $T_{\mathrm{E}}$, the final $z$-value will be obtained.

$z=\frac{T_{\mathrm{E}_{1}}-T_{\mathrm{E}_{2}}}{\left(\log \frac{D_{\mathrm{E}_{2}}}{D_{\mathrm{E}_{1}}}\right)}$.

\section{Materials and methods}

\section{1. Сupuaçu nectar preparation}

Frozen Cupuaçu pulp was imported from Brazil in $1-\mathrm{kg}$ bags. A nectar with a composition of $25 \%$ Cupuaçu, $15 \%$ sugar, $50 \%$ water, and $10 \%$ of a spore suspension containing $10^{5} \mathrm{~A}$. acidoterrestris spores/ $\mathrm{ml}$ was prepared. Before adding the spore suspension, the mixture was homogenized with a Moulinex Turbomix 2 blender, for $3 \mathrm{~min}$ and passed through a plastic strainer. In order to define the initial population, appropriate dilutions were then made in order to enumerate the spores by the method described below.

\subsection{Suspension of A. acidoterrestris spores}

A spore suspension of $A$. acidoterrestris, strain NCIMB 13137 (National Collections of Industrial and Marine Bacteria, Auris Business Centre, Aberdeen, UK), was prepared by adding a portion of freeze-dried spores, previously produced by Silva et al. (1999), to a flask containing $200 \mathrm{ml}$ of sterile water and glass beads. The suspension was then kept in the cold at $4{ }^{\circ} \mathrm{C}$ and shaken several times a day in order to destroy clumps before proceeding to enumeration. A $10^{-1}$-dilution was then done, to obtain $100 \mathrm{ml}$ of a working solution, and the original suspension was frozen and stored in a freezer at $-18{ }^{\circ} \mathrm{C}$.

\subsection{Enumeration of spores}

The spores were first observed by phase contrast microscopy. A great majority of the spores were refringent. Then, using a Newerbauer chamber, the concentration of the suspension was determined by direct microscopy count. The counting was performed five times and the results were averaged. The spores were also enumerated using the method developed by Pettipher et al. (1997): $0.1 \mathrm{ml}$ spread onto orange serum agar (OSA) (Merck) plates, followed by incubation at $44{ }^{\circ} \mathrm{C}$ for $48 \mathrm{~h}$. Although this method had been optimized for a different strain, A. acidoterrestris 2498 , recovery of the strain used in this study (NCIMB 13137) was very good as well.

\subsection{Modeling the kinetics of thermal inactivation of A. acidoterrestris spores}

\subsubsection{Isothermal experiments}

For each thermal treatment, 2-ml vials (Chrompack) were filled with the inoculated nectar, sealed, and placed in a rack. Next, they were immersed in an oil bath (Grant W38) preset at the desired temperature for the thermal treatment. The vials were taken out of the oil bath, after the required holding time, and immediately cooled down to $4{ }^{\circ} \mathrm{C}$ in an iced water bath to stop the heat treatment immediately. Five temperatures were studied $(90,95,100,105$, and $110{ }^{\circ} \mathrm{C}$ ) for holding times ranging from 0 to 40 min. After the thermal treatment, from each vial, appropriate dilutions were made to enumerate the survivor population by the method described above. As vials were used, instead of capillary tubes, it was not expected that the studied temperatures would be instantly reached. To obviate this problem, a replicate study was carried out with thermocouples placed within the vials of spore suspension for the purpose of determining the come-up time (CUT). Zero time and the corresponding initial count were considered only after the CUT. This procedure had the advantage of heat shocking the spores and freeing the nectar from any vegetative cells present during the CUT. 
However, additional lethality contributed during cooldown times (CDT) could not be considered. Three isothermal studies were carried out with the same spore solution, Experiment 1-right after rehydration, Experiment 2-4 months after frozen storage, and Experiment 3-8 months after frozen storage. Between studies, the spore solution was kept frozen in a freezer at $-18{ }^{\circ} \mathrm{C}$. Before each experiment, the spores were observed microscopically and spore enumeration was performed as described above.

\subsubsection{Dynamic thermal treatments}

Seven different thermal exposures were applied to Cupuaçu nectar. The tests were conducted under nonuniform heating conditions, using the same spore suspensions as in IM Experiment 3 (after 8 months of frozen storage). A plate heat exchanger and a holding tube were used (Armfield Pasteuriser FT-43A), as described in Vieira et al. (2001). In order to produce different $t_{\mathrm{E}}$ and $T_{\mathrm{E}}$, different processing temperatures and flow rates were used. The pasteurizer had 32 plates in the heating section and the holding tube was composed of three sections, immersed in a water bath set at the temperature needed. Before, and between runs, the whole system was sanitized by running a hypochlorite solution (500 ppm) for $15 \mathrm{~min}$, followed by running hot water at $95{ }^{\circ} \mathrm{C}$ for $10 \mathrm{~min}$ (procedure described by Wescott et al., 1995). For each run, three samples were collected, each in decontaminated flasks.

\subsection{Time-temperature history}

In order to obtain the time-temperature history, an element of volume $\mathrm{d} v$ was dyed with a $2 \%(\mathrm{w} / \mathrm{v})$ solution of methylene blue, by injecting $1 \mathrm{ml}$ at the entrance of the feeding tube at time 0 . The temperature changes in $\mathrm{d} v$ were monitored along the pathway by inserting TCT thermocouples between the pasteurizer plates on the product side and at the entrance and exit of each holding tube section and cooling tube. The temperature data were recorded by a data acquisition system (Delta Logger devices). The corresponding traveling time of $\mathrm{d} v$ (from the entrance to each site of insertion of a thermocouple) was recorded using a stopwatch and visual detection of the blue dyed nectar, following the method described in Vieira et al. (2001).

\subsection{Data analysis}

The kinetic data obtained in the isothermal experiments were analyzed using the isothermal method (IM). A one-step nonlinear regression to all the data, using the software STATA (Stata Corporation, 1995), was carried out as described in Vieira et al. (2000).

A FORTRAN program was developed 'Kinprmbglow', to apply the PEIE method step by step (Welt et al., 1997; Vieira et al., 2001) using the Bigelow model.

The following modifications were introduced:

1. after the stabilization of the iterations, the $D_{\mathrm{E}}$ values were calculated from the EIE data $\left(T_{\mathrm{E}}\right.$ and $\left.t_{\mathrm{E}}\right)$ and experimental thermal destruction of $A$. acidoterrestris spores (Eq. (9));

2. from a plot of $\log D_{\mathrm{E}}$ vs. $T_{\mathrm{E}}$, the final $z$-value and $D_{\text {ref }}$ were obtained (Eq. (10)).

\section{Results and discussion}

\subsection{Spore enumeration}

The spores enumerated by direct count $\left(1.95 \times 10^{6}\right.$ c.f.u./ml) were just slightly lower (but not significantly different) than the number counted by spread plating $\left(2.00 \times 10^{6}\right.$ c.f.u. $\left./ \mathrm{ml}\right)$. However, in most cases, the opposite occurred because usually a small percentage of the spores was not viable and therefore, could be seen with a microscope and directly counted, but did not grow in any media (not counted by spread plating). According to Bourgeois and Malcoste (1995), the number of counts in counting chambers should be three. In this particular case, although five counts were used, the existence of clumps might have caused this behavior.

\subsection{Isothermal method (IM)}

The results obtained from the isothermal experiments (Fig. 1) were well fitted by the Bigelow model (Eq. (4)). The kinetic parameters, $z$ and $D_{95}{ }^{\circ} \mathrm{C}$, obtained, using a one-step nonlinear regression, are presented in Table 1 for each isothermal study (Experiments 1, 2, and 3).

The $z$-value for Experiment 1 is in agreement with the already published $z$-values for other strains of this 

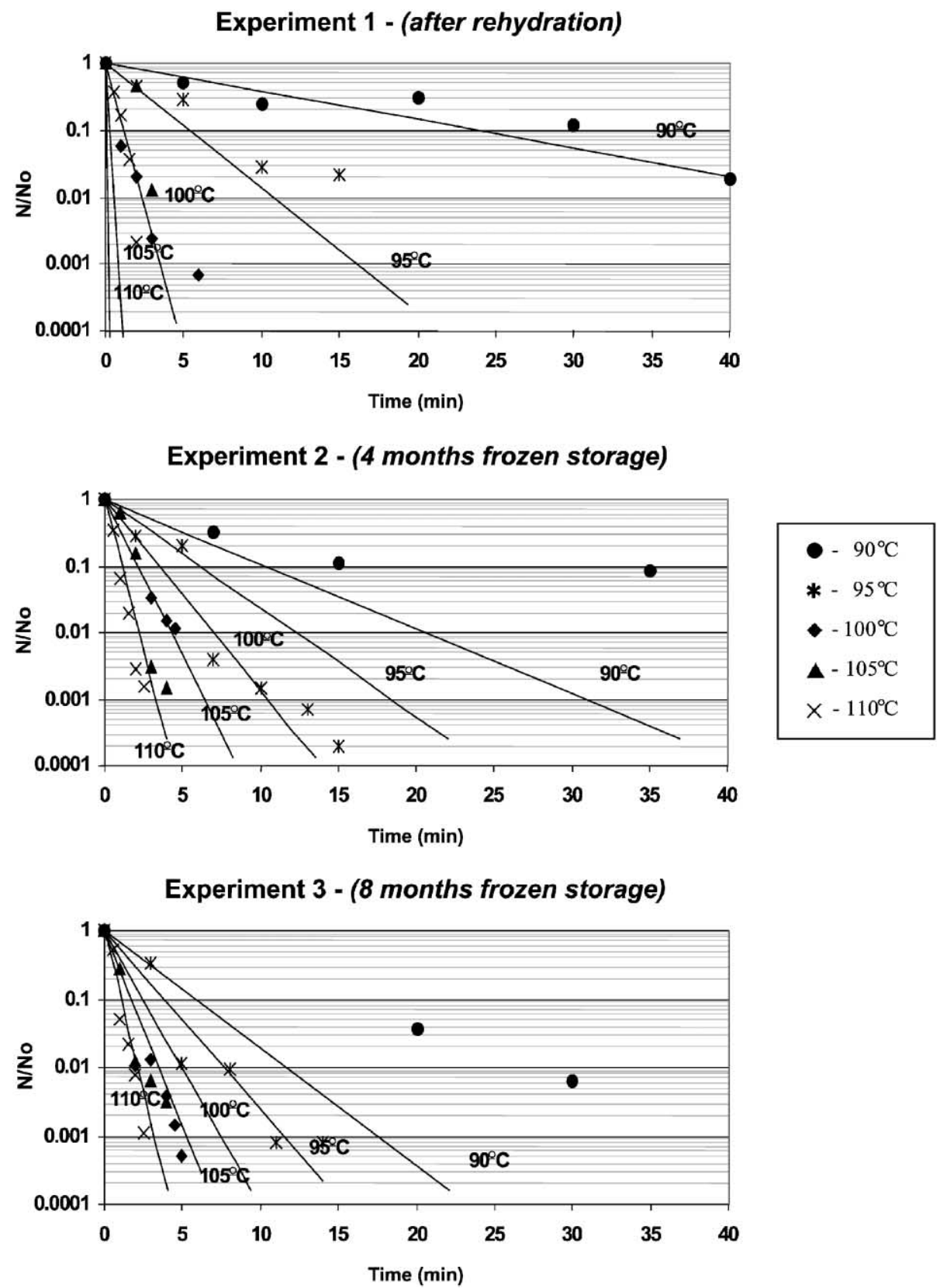

Fig. 1. Effect of temperature and time on the degradation of $A$. acidoterrestris spores in Cupuaçu nectar (pH 3.2 and $18^{\circ}$ Brix).

microorganism in fruit juices, especially with the ones by Eiroa et al. (1999) and Splittstoesser et al. (1994) (Table 2). Concerning the $D$ values, a higher value is obtained for the Cupuaçu nectar (Table 1), which might be a result of the higher soluble solids content.
Experiments 2 and 3 were meant to confirm the results of the first study. However, it was verified that the behavior of the spores changed considerably. The spores' thermal degradation sensitivity to temperature changes decreased from Experiment 1 to Experiment 3, 
Table 1

Thermal reduction kinetic parameters for A. acidoterrestris spores in Cupuaçu nectar, using the isothermal method (IM) (18 ${ }^{\circ}$ Brix, $\left.\mathrm{pH} 3.2\right)$

\begin{tabular}{llll}
\hline & \multicolumn{2}{l}{ Isothermal method } & Experiment 3 \\
\cline { 2 - 4 } & $\begin{array}{l}\text { Experiment 1 } \\
\text { (after rehydration) }\end{array}$ & $\begin{array}{l}\text { Experiment 2 } \\
\text { (4 months frozen storage) }\end{array}$ & $3.82 \pm 0.48$ \\
\hline$D_{95}{ }^{\circ} \mathrm{C}(\mathrm{min})$ & $5.29 \pm 0.96$ & $5.99 \pm 0.63$ & $29 \pm 10$ \\
$z\left({ }^{\circ} \mathrm{C}\right)$ & $7.8 \pm 2.6$ & $22 \pm 5$ & 0.98 \\
$R^{2}$ & 0.97 & 0.97 & 26 \\
No. of observations & 25 & 27 & 26 \\
\hline
\end{tabular}

as it can be observed by the increase in the $z$-value (Table 1). This behavior might have been caused by the aging under frozen storage between the experiments. So far, no studies were reported on the influence of frozen storage on the behavior of the spores of $A$. acidoterrestris. Alpin and Hodges (1979) reported the influence of storage temperature on the spores of a different microorganism, B. stearothermophilus, but they observed a different behavior. The spores of this Bacillus species, when stored at $-18{ }^{\circ} \mathrm{C}$, exhibited a loss in viability and heat resistance after 8 days of storage. Food safety considerations would dictate that thermal process design be based upon the worse case possible for spores found in nature. Therefore, the highest $z$-values (least temperature sensitivity) should be adopted for this purpose.

\subsection{PEIE method}

In Fig. 2, the thermal profiles from the seven dynamic experiments are presented, and the corresponding inactivation data of $A$. acidoterrestris spores are shown in Table 3. These results were used in the PEIE method to evaluate the kinetic parameters. Although 21 combinations were expected, giving 42 data points, 10 combinations were lost. This fact is

Table 2

Thermal inactivation kinetic parameters of several strains of $A$. acidoterrestris spores in different juices

\begin{tabular}{|c|c|c|c|c|c|c|c|}
\hline Juice & Strain & SS & $\mathrm{pH}$ & $\begin{array}{l}\text { Temperature } \\
\left({ }^{\circ} \mathrm{C}\right)\end{array}$ & $D$ value (min) & $z$-Value $\left({ }^{\circ} \mathrm{C}\right)$ & Reference \\
\hline Apple & & $\mathrm{nr}^{\mathrm{a}}$ & 3.51 & $\begin{array}{l}80 \\
90 \\
95\end{array}$ & $\begin{array}{r}41.15 \pm 0.24 \\
7.38 \pm 0.85 \\
2.30 \pm 0.03\end{array}$ & 12.2 & Komitopoulou et al., 1999 \\
\hline Grapefruit & Z CRA 7182 & $\mathrm{nr}^{\mathrm{a}}$ & 3.42 & $\begin{array}{l}80 \\
90 \\
95\end{array}$ & $\begin{array}{r}37.87 \pm 0.20 \\
5.95 \pm 0.32 \\
1.85 \pm 0.05\end{array}$ & 11.6 & \\
\hline Orange & & $\mathrm{nr}^{\mathrm{a}}$ & 3.90 & $\begin{array}{l}80 \\
90 \\
95\end{array}$ & $\begin{array}{r}54.30 \pm 0.42 \\
10.30 \pm 0.30 \\
3.59 \pm 0.04\end{array}$ & 12.9 & \\
\hline Orange & DSM2498 & $\mathrm{nr}^{\mathrm{a}}$ & $\mathrm{nr}^{\mathrm{a}}$ & $\begin{array}{l}85 \\
90 \\
95\end{array}$ & $\begin{array}{r}50.00 \pm \mathrm{nr} \\
16.90 \pm \mathrm{nr} \\
2.70 \pm \mathrm{nr}\end{array}$ & 7.9 & Eiroa et al., 1999 \\
\hline Apple & $\mathrm{VF}$ & 11.4 & 3.50 & $\begin{array}{l}85 \\
90 \\
95\end{array}$ & $\begin{array}{c}56.00 \pm 14.00 \\
23.00 \pm 7.50 \\
2.80 \pm 0.70\end{array}$ & 7.7 & Splittstoesser et al., 1994 \\
\hline Grape & WAC & 15.8 & 3.30 & $\begin{array}{l}85 \\
90 \\
95\end{array}$ & $\begin{array}{c}57.00 \pm 13.00 \\
16.00 \pm 4.10 \\
2.40 \pm 0.90\end{array}$ & 7.2 & \\
\hline Cupuaçu extract & NCIMB 13137 & 11.3 & 3.60 & $\begin{array}{l}85 \\
91 \\
95 \\
97\end{array}$ & $\begin{array}{r}17.50 \pm 1.10 \\
5.35 \pm 0.57 \\
2.82 \pm 0.27 \\
0.57 \pm 0.03\end{array}$ & 9.0 & Silva et al., 1999 \\
\hline
\end{tabular}

\footnotetext{
${ }^{\mathrm{a}} \mathrm{nr}-$ not reported.
} 


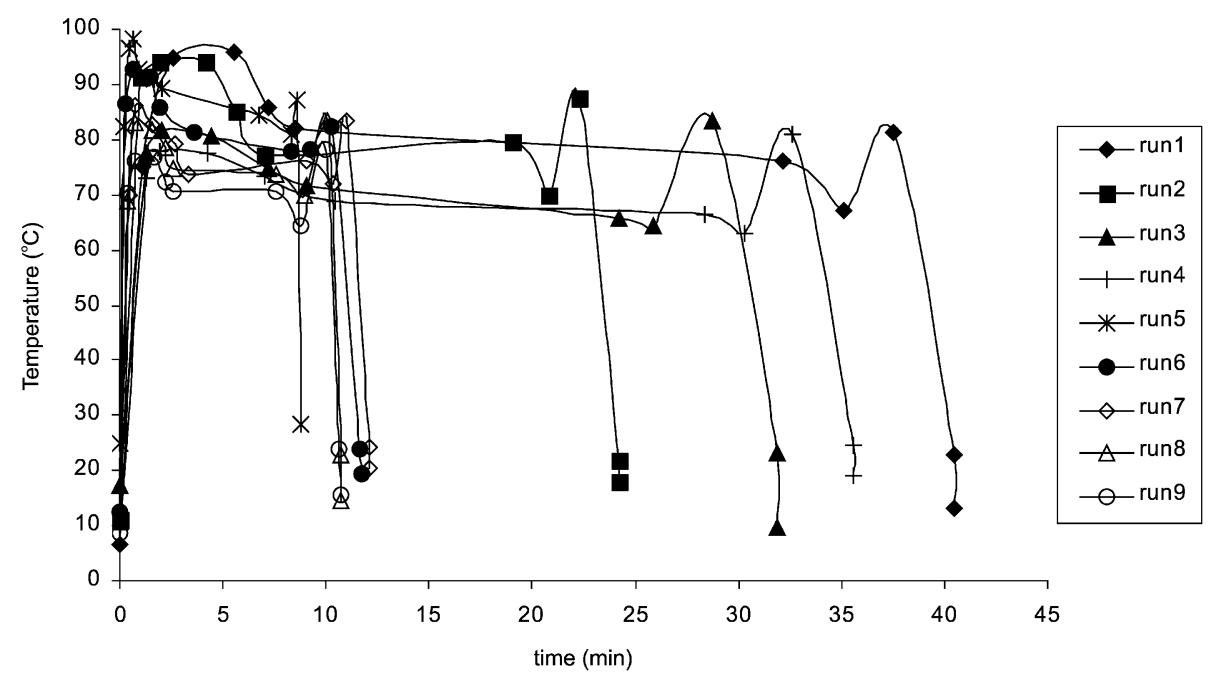

Fig. 2. Time-temperature histories for all seven runs.

explained by the presence of combinations that either lead to negative values of $E_{\mathrm{a}}$ (if in a combination, $T_{\mathrm{E} 1}<T_{\mathrm{E} 2}$ and $k_{\mathrm{E} 1}>k_{\mathrm{E} 2}$, or vice versa) or to $E_{\mathrm{a}}$ values too high or too low, when compared to the average values (existence of very close values of $T_{\mathrm{E}}$ or $t_{\mathrm{E}}$ ) (Welt et al., 1997). By applying the Bigelow model to the data obtained ( $D_{\mathrm{E}}$ 's and corresponding $\mathrm{T}_{\mathrm{E}}$ 's) and through regression analysis (Fig. 3), a $z$-value of $31 \pm 6{ }^{\circ} \mathrm{C}$ and a $D_{95}{ }^{\circ} \mathrm{C}$ of $5.5 \pm 1.2$ min were obtained (Table 4, Fig. 3). Both the $R^{2}$ of 0.87 and the residuals analysis performed (Fig. 4) indicated that the regression line obtained, with the estimated parameters, presented a good fit. Residuals higher than 0.2 were considered as outliers and were discarded. The inactivation data predicted by the model is also

Table 3

Experimental final reduction of $A$. acidoterrestris spores in Cupuaçu nectar for all continuous thermal treatments

\begin{tabular}{lllll}
\hline Run \# & $\begin{array}{l}\text { Flow rate } \\
(1 / \mathrm{h})\end{array}$ & $\begin{array}{l}\text { Maximum } \\
\text { temperature } \\
\text { reached }\left({ }^{\circ} \mathrm{C}\right)\end{array}$ & $N / N_{\text {0exp }}$ & $N / N_{\text {Opred }}$ \\
\hline 1 & 0.28 & 99 & 0.012 & 0.002 \\
2 & 0.46 & 95 & 0.037 & 0.023 \\
3 & 0.4 & 85 & 0.067 & 0.080 \\
4 & 2.9 & 99 & 0.083 & 0.120 \\
5 & 0.3 & 80 & 0.118 & 0.100 \\
6 & 2.8 & 90 & 0.254 & 0.280 \\
7 & 2.8 & 85 & 0.123 & 0.350 \\
\hline
\end{tabular}

presented in Table 3 and compared with results from isothermal Experiment 3.

Comparison of Table 1 (Experiment 3) and Table 4 shows that the results obtained from both methods are close, although for the PEIE method (continuous system), both the $z$-value and the $D_{95}{ }^{\circ} \mathrm{C}$ were higher. This behavior can be interpreted as a consequence of failure to account for added lethality contributed to cool-down time that could not be accounted for in isothermal experiments, especially at higher temperatures when lethality occurs very rapidly in a short time. This difference in $z$-values, between isothermal and continuous methods, was already noticed on other occasions (Table 5).

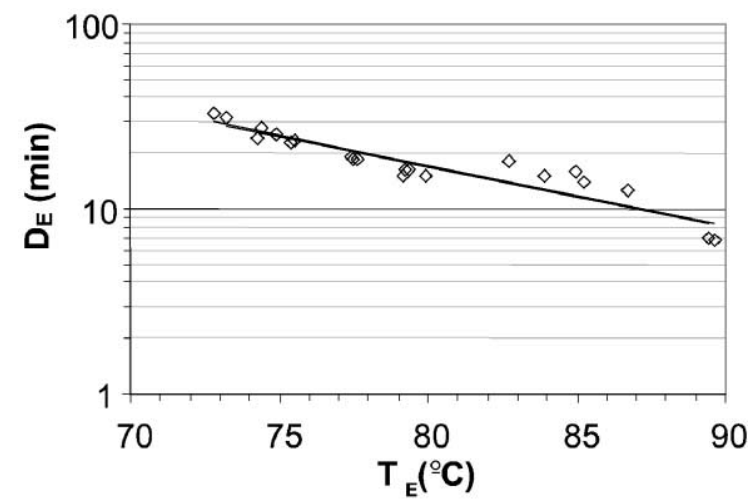

Fig. 3. PEIE Bigelow plot, obtained using all seven dynamic thermal treatments, after 12 iterations. 
Table 4

Kinetic parameters of thermal inactivation of A. acidoterrestris spores in Cupuaçu nectar (18 Brix, pH 3.2) using the PEIE method and Experiment 3 of the IM method

\begin{tabular}{lll}
\hline & PEIE method & IM Experiment 3 \\
\hline$D_{95}{ }^{\circ} \mathrm{C}(\mathrm{min})$ & $5.5 \pm 1.2$ & $3.82 \pm 0.48$ \\
$z\left({ }^{\circ} \mathrm{C}\right)$ & $31 \pm 6$ & $29 \pm 10$ \\
$R^{2}$ & 0.87 & 0.98 \\
No. of observations & 22 & 26 \\
\hline
\end{tabular}

As mentioned above, in the isothermal study, the increase in the $z$-value from experiment to experiment was probably due to spore injury caused by being frozen under storage, 4 months from Experiment 1 to Experiment 2 and then another 4 months to Experiment 3. Again, for purposes of food safety, this must be assumed indicative of the heat resistance exhibited by these spores when found in nature.

\subsection{Optimization of thermal process}

The objective function in this study is to maximize the retention of ascorbic acid, AA, having as decision variables: (i) the steam pressure that affects the heating fluid temperature (in this case water) and (ii) the flow rate of the Cupuaçu nectar, which will directly affect the holding time. A $5 D$ reduction in $A$. acidoterrestris spores was imposed as a constraint (FDA, 1998). This optimization was only possible because of the different kinetic parameters for both AA and $A$. acidoterrestris spores, as generally, bacteria have lower $z$-values (much more heat sensitive to temperature changes) compared with quality parameters. Therefore, an increase in temperature will benefit retention of quality parameters for the same level of

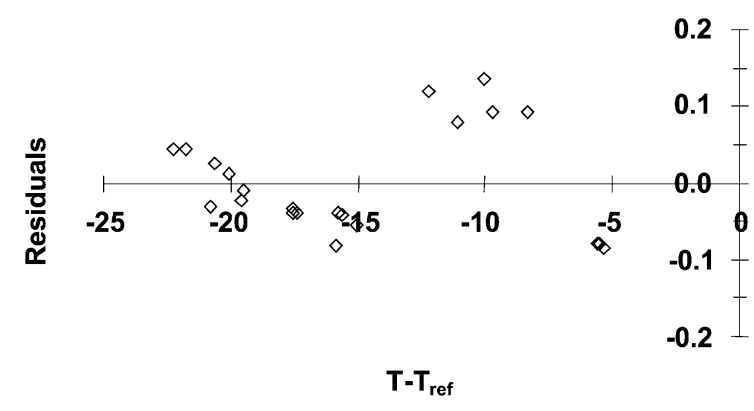

Fig. 4. Residuals analysis of the regression of $D_{\mathrm{E}}$ vs. $T_{\mathrm{E}}$.
Table 5

$z$-values determined using a batch and a continuous system

\begin{tabular}{llll}
\hline Reference & \multicolumn{2}{l}{ z-value $\left({ }^{\circ} \mathrm{C}\right)$} & $\begin{array}{l}\text { Type of } \\
\text { microorganism }\end{array}$ \\
\cline { 2 - 3 } & Batch & Continuous & \\
\hline Bunning et al., 1988 & $7^{\mathrm{a}}$ & 7.3 & Listeria \\
Fairchild et al., 1994 & $4.8^{\mathrm{a}}$ & 5.9 & $\begin{array}{l}\text { Listeria innocua } \\
\text { Bacillus cereus }\end{array}$ \\
& & $8.2^{\mathrm{b}}$ & \\
Wescott et al., 1995 & $8.5^{\mathrm{a}}$ & $8.5^{\mathrm{c}}$ & \\
& & $7.5^{\mathrm{b}}$ & $\begin{array}{l}\text { Bacillus } \\
\text { stearothermophilus }\end{array}$ \\
Mackey and Bratchel, & $6.1^{\mathrm{a}}$ & $7.3^{\mathrm{c}}$ & \\
1989 & & 7.4 & $\begin{array}{l}\text { Listeria } \\
\text { monocytogenes }\end{array}$ \\
\hline
\end{tabular}

${ }^{\text {a }}$ Capillary tube method.

b Traditional method.

c Equivalent point method.

inactivation in bacteria (HTST-high temperature short time principle) (Holdsworth, 1985).

A simple optimization technique was chosen: a search for the best time-temperature combinations that would maximize the retention of AA, keeping the level of inactivation of $A$. acidoterrestris spores $(5 D)$. Fig. 5 is a semilogarithmic plot of time vs. temperature where thermal degradation lines for AA (dashed lines) are superimposed on a thermal death time (TDT) curve for A. acidoterrestris spores (thick line) (Teixeira and Shoemaker, 1989). The dashed lines, obtained from the kinetic data of thermal degradation of AA evaluated (Vieira et al., 2001) using the PEIE method, represent time-temperature combinations that keep a retention of $55-98.5 \%$ of AA. The coarse line 1 (constraint) was obtained from the kinetic data for $A$. acidoterrestris spores using the isothermal method (Table 1, Experiment 1) for illustrative purposes. Unfortunately, the kinetic data from the PEIE method (IM Experiments 2 and 3 as well) produced $z$ values $\left(z=30{ }^{\circ} \mathrm{C}\right)$ close to those for AA degradation $\left(z=38{ }^{\circ} \mathrm{C}\right)$. Under these conditions, there would be limited opportunity for optimization. Coarse line 1 (Fig. 5) represents time-temperature combinations that yield a $5 D$ reduction in $A$. acidoterrestris spores (assuming a $z$ of $7.8{ }^{\circ} \mathrm{C}$ ). From the interception of the coarse line 1 with the dashed lines, two thermal treatments are obtained: (A) in the pasteurization temperature range (with $55 \%$ AA retention): $98{ }^{\circ} \mathrm{C}$ during $9 \mathrm{~min}$, and (B) in the sterilization temperature range (98.5\% AA retention): $115{ }^{\circ} \mathrm{C}$ during $8 \mathrm{~s}$. It 


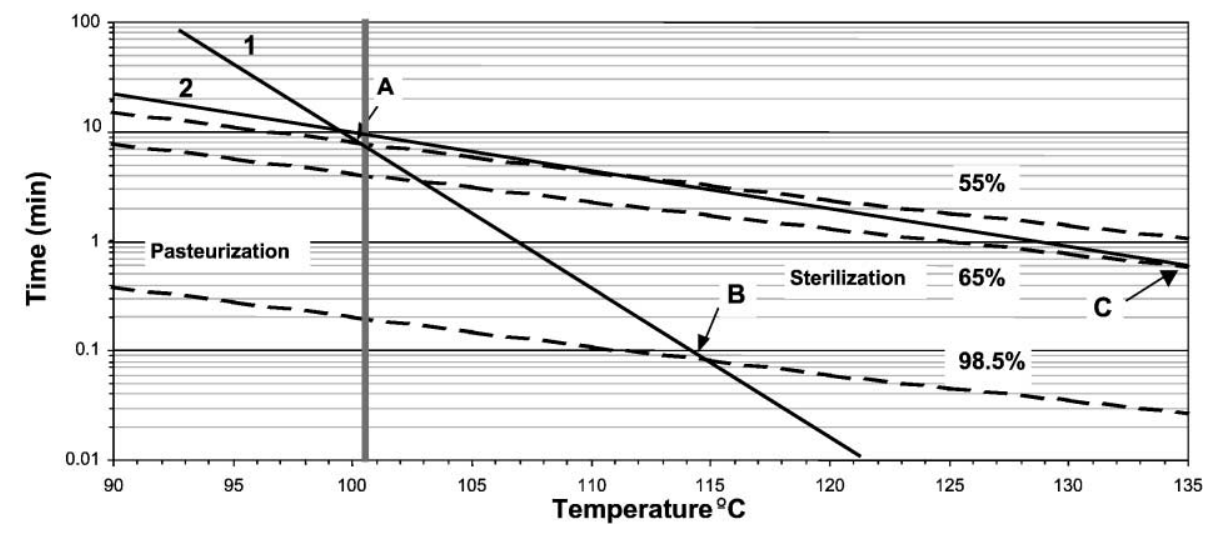

Fig. 5. Graphical optimization for thermal processing of Cupuaçu nectar. Coarse lines 1 and 2 are both for a $5 D$ reduction on A. acidoterrestris spores, assuming $z=7.8{ }^{\circ} \mathrm{C}$ and $z=30{ }^{\circ} \mathrm{C}$, respectively, and the three dashed lines are from top to bottom, respectively, for $55 \%$, $65 \%$, and $98.5 \%$ AA retention. A vertical gray line separates the pasteurization from sterilization range of temperatures. The arrows indicate the three optimal time-temperature combinations: (A) $9 \mathrm{~min}, 98^{\circ} \mathrm{C}$; (B) $8 \mathrm{~s}, 115^{\circ} \mathrm{C}$; and (C) $36 \mathrm{~s}, 135{ }^{\circ} \mathrm{C}$.

should be noted that these conditions do not apply if process designs were to be based upon the worse case $z$-values of $29-30{ }^{\circ} \mathrm{C}$ for aged spores, as shown in coarse line 2 for illustrative purposes. In this case, the best ascorbic acid retention would be expected to be $65 \%$ or less to satisfy the $5 D$ constraint under feasible time-temperature conditions, as this line intercepts the $A$. acidoterrestris coarse line 2 at $135{ }^{\circ} \mathrm{C}$ and $36 \mathrm{~s}$ (Fig. 5, point C).

\section{Conclusions}

From this work, it seems that the PEIE method can also be applied to estimate the thermal inactivation kinetic parameters of a spore-forming microorganism in a more realistic way. Therefore, when designing a thermal process for a continuous system, the PEIE method should be used to estimate the reduction kinetic parameters (if instantaneous heating and cooling are not possible with traditional isothermal experiments), or chances are, that the process would be underdesigned, risking that the desired spore population reduction would not be achieved.

If $A$. acidoterrestris spores are considered as the target microorganisms, then it is recommended that Cupuaçu nectar should undergo an aseptic HTST process in the sterilization temperature range to achieve a $5 D$ reduction. However, if the hot-fill-and- hold pasteurization process is preferred (because it can be a more appropriate and simple technology), then the product should be fortified with ascorbic acid, or packaged with minimum headspace to limit the availability of oxygen that is needed in order for the degradation reaction to proceed.

\section{References}

Alpin, S.J., Hodges, N.A., 1979. Changes in heat resistance during storage of Bacillus stearothermophilus spores produced in chemically defined media. Journal of Applied Bacteriology 46, 623-626.

Bigelow, W.D., 1921. The logarithmic nature of thermal death time curves. Journal of Infectious Diseases 34, 528-536.

Blocher, J.C., Busta, F.F., 1983. Bacterial spore resistance to acid. Food Technology 37, 87.

Bourgeois, G.M., Malcoste, R., 1995. Microbial Control for Foods and Agricultural Products. VCH Publishers, UK, p. 47, Chap. 4.

Bunning, V.K., Donnely, C.W., Peeler, J.T., Briggs, E.H., Bradshaw, J.G., Crawford, R.G., Beliveau, C.M., Tierney, J.T., 1988. Thermal inactivation of Listeria monocytogenes within bovine milk phagocytes. Applied and Environmental Microbiology 54, $364-378$.

Cerny, G., Hennlich, W., Poralla, K., 1984. Fruchtsaftverderb durch bacillen: isolierung und charakterisierung des verderbseregers. Zeitschrift fuer Lebensmittel-Untersuchung und-Forschung 179, 224-227.

Deinhard, G., Blanz, P., Poralla, K., Altan, E., 1987. Bacillus acidoterrestris sp. nov., a new thermotolerant acidophile isolated from different soils. Systematic and Applied Microbiology 10, $47-53$. 
Eiroa, M.N.U., Junqueira, V.C.A., Schmidt, F.L., 1999. Alicyclobacillus in orange juice: occurrence and heat resistance of spores. Journal of Food Protection 62 (8), 883-886.

Etsy, J.R., Myer, K.F., 1922. The heat resistance of the spores of $C$. botulinum and allied anaerobes. Journal of Infectious Diseases 34, 650-663.

Fairchild, T.M., Swartzel, K.R., Foegeding, P.M., 1994. Inactivation kinetics of Listeria innocua in skim milk in a continuous flow processing system. Journal of Food Science 59 (5), 960-963.

FDA, 1998. Hazard Analysis Critical Control Point (HACCP); Procedures for the safe and sanitary processing and importing of juice. Department of Heath and Human Services. 63 FR 20450.

Geankoplis, C., 1993. Drying of process materials. Transport Processes and Unit Operations, 3rd ed. Prentice-Hall, USA, pp. 520-583, Chap. 9.

Holdsworth, S.D., 1985. Optimization of thermal processing-a review. Journal of Food Engineering 4, 89-116.

Komitopoulou, E., Boziaris, I.S., Davies, E.A., Dalves-Broughton, J., Adams, M.R., 1999. Alicyclobacillus acidoterrestris in fruit juices and its control by nisin. International Journal of Food Science and Technology 34, 81-85.

Kyereme, M., Swartzel, K.R., Farkas, B.E., 1999. New line intersection procedure for the equivalent point method of thermal evaluation. Journal of Food Science 64 (4), 565-570.

Lenz, M.K., Lund, D.B., 1980. Experimental procedures for determining destruction kinetics of food components. Food Technology, 51 .

Mackey, B.M., Bratchel, N., 1989. A review: the heat resistance of Listeria monocytogenes. Letters in Applied Microbiology 9, 89-94.

Maesmans, G., Hendrickx, M., De Cordt, S., Tobback, P., 1995. Theoretical consideration of the general validity of the equivalent point method in thermal process evaluation. Journal of Food Engineering 24, 225-248.

Pettipher, G.L., Osmundson, M.E., Murphy, J.M., 1997. Methods of detection and enumeration of Alicyclobacillus acidoterrestris and investigation of growth and production of taint in fruit juice and fruit juice-containing drinks. Letters in Applied Microbiology 24, 185-189.

Pontius, A.J., Rushing, J.E., Foegeding, P.M., 1998. Heat resistance of Alicyclobacillus acidoterrestris spores as affected by various $\mathrm{pH}$ values and organic acids. Journal of Food Protection 61 (1), $41-46$.

Rodrigo, M., Martinez, A., Sanchis, J., Trama, J., Giner, V., 1990. Determination of hot-fill-hold-cool process specifications for crushed tomatoes. Journal of Food Science 55 (4), 1029-1032, 1038.

Sandoval, A.J., Barreiro, J.A., Mendoza, S., 1992. Thermal resistance of Bacillus coagulans in double concentrated tomato paste. Journal of Food Science 57 (6), 1369-1370.

Silva, F.M., Gibbs, P., Vieira, M.C., Silva, C.L.M., 1999. Thermal inactivation of Alicyclobacillus Acidoterrestris spores under different temperature, soluble solids and $\mathrm{pH}$ conditions for the design of fruit processes. International Journal of Food Microbiology 51, 95-103.

Solberg, P., Castberg, H.B., Osmunsen, J.I., 1990. Packaging systems for fruit juices and non-carbonated beverages. In: Hicks, D. (Ed.), Production and Packaging of Non-carbonated Fruit Juices and Fruit Beverages, 1st ed. Blackie and Son, London, p. 330 Chap. 12.

Splittstoesser, D.F., Churey, J.J., Lee, C.Y., 1994. Growth characteristics of aciduric sporeforming Bacilli isolated from fruit juices. Journal of Food Protection 57 (12), 1080.

Stata Corporation, 1995. Stata Statistical Software: Release 4.0 college station.

Stumbo, C.R., 1973. Death of bacteria subjected to moist heat. Thermobacteriology in Food Processing, 2nd ed. Academic Press, New York, USA, Chap. 7.

Swartzel, K.R., 1982. Arrhenius kinetics as applied to product constituent losses in ultra-high temperature processing. Journal of Food Science 47, 1886-1891.

Teixeira, A.A., Shoemaker, C.F., 1989. Process optimization. In: Teixeira, A.A., Shoemaker, C.F. (Eds.), Computerized Food Processing Operations. Van Nostrand-Reinhold, New York, USA, p. 169, Chap. 6.

Vieira, M.M.C., Teixeira, A.A., Silva, C.L.M., 2000. Mathematical modeling of the thermal degradation kinetics of vitamin $\mathrm{C}$ in Cupuaçu (Theobroma grandiflorum) nectar. Journal of Food Engineering 43, 1-7.

Vieira, M.M.C., Teixeira, A.A., Silva, C.L.M., 2001. Kinetic parameters for ascorbic acid degradation in fruit nectar using the Paired Equivalent Isothermal Exposures (PEIE) method under non-isothermal continuous heating conditions. Biotechnology Progress 17, 175-181.

Walls, I., Chuyate, R., 1998. Alicyclobacillus. Historical perspective and preliminary characterization study. Dairy, Food and Environmental Sanitation 18 (8), 499-503.

Welt, B.A., Teixeira, A.A., Balaban, M.O., Semerage, G.H., Sage, D.S., 1997. Iterative method for kinetic parameter estimation from dynamic thermal treatments. Journal of Food Science 62 (1), 8 .

Wescott, G.G., Fairchild, T.M., Foegeding, P.M., 1995. Bacillus cereus and Bacillus stearothermophilus spores inactivation in batch and continuous flow systems. Journal of Food Science 60 (3), 446-450.

Yamazaki, K., Teduka, H., Shinano, H., 1996. Isolation and identification of Alicyclobacillus acidoterrestris from acidic beverages. Bioscience, Biotechnology, and Biochemistry 60 (3), $543-545$.

York, G.K., Heil, J.R., Marsh, G.L., Merson, R.L., Wolcott, T., Leon, S., 1975. Thermobacteriology of canned whole peeled tomatoes. Journal of Food Science 40, 764-769. 